\title{
ANALISA GENDER DAN PRINSIP PRINSIP PENAFSIRAN HUSEIN MUHAMMAD PADA AYAT-AYAT RELASI GENDER
}

\author{
Eni Zulaiha \\ Fakultas Ushuluddin UIN Sunan Gunung Djati Bandung \\ Jl. AH. Nasution 105 Cibiru Bandung \\ Email : eni258433@gmail.com
}

\begin{abstract}
So far the majority of commentators have made efforts to understand the interpretation of the Qur'an with a literalscriptural approach. The results of this approach are considered to have given rise to gender-biased interpretation. Today, especially contemporary feminist scholars have used gender analysis and contextual-philosophical approaches in their interpretations, the results of their interpretation have been assessed as gender fair. Hussein Muhammad as one of the Indonesian feminist commentators has also succeeded in carrying out a contextualphilosophical approach and incorporating gender analysis in his interpretation, methodology the feminist interpretation he built was interesting. the interpretation of epistemology intersects with the contemporary epistemology of contemporary interpretations that is different from the classical interpretation. The principle of interpretation has integrated gender analysis from the West into a study that does not contradict the opinions of classical scholars. He continued to use the hermeneutic approach in his interpretation but did not abandon the logic of Islamic law which had been popular among Muslim scholars. The subject matter in this paper was reviewed by analytical descriptive methods and data search techniques using book surveys and interviews. The results of this study found nine interpretive principles of Husein Muhammad. The conclusion in this paper, actually the interpretation of Husein Muhammad concentrates on the study of the historicity of the Quranic text as well as the understanding of the text that focuses on the relation of the text, context, and author
\end{abstract}

\section{Kata Kunci:}

gender; Husein Muhammad, contemporary interpretation; the historicity of the text.

\begin{abstract}
Abstrak
Selama ini mayoritas mufasir telah melakukan upaya pemahaman penafsiran terhadap Alquran dengan pendekatan literal-skriptural. Hasil pendekatan ini dinilai telah melahirkan penafsiran yang bias gender. Dewasa ini ulama kontemporer hususnya feminis telah menggunakan analisa gender dan pendekatan kontekstual-filosofis dalam penafsirannya, hasil penafsirkan mereka berhasil dinilai adil gender.Husein Muhammad sebagai salah satu mufasir feminis Indonesia juga telah berhasil melakukan pendekatan kontekstual-filosofis dan memasukan analisa gender dalam penafsirannya, metodologi tafsir feminis yang dibangunnya cukup menarik. epistemologi penafsirannya beririsan dengan epistemologi tafsir kontemporer yang tentunyaberbeda dengan tafsir klasik. Prinsip penafsirannya telah memadukan analisa gender yang berasal dari Barat itu menjadi kajian yang tidak bersebrangan dengan pendapat ulama-ulama klasik sekalipun. Ia tetap menggunakan pendekatan hermeneutika dalam tafsirnya namun tidak meninggalkan logika- logika hukum Islam yang selama ini populer di kalangan sarjana muslim. Pokok bahasan dalam tulisan ini dikaji dengan metode deskriptif analitis dan tehnik pencarian data menggunakan book survey dan wawancara. Hasil dari penelitian ini menemukan sembilanprinsip penafsiran Husein Muhammad. Kesimpulan dalam tulisan ini, sebenarnya penafsiran Husein Muhammad berkonsentrasi pada kajian historisitas teks Alquran juga pola pemahaman teks yang memfokuskan pada relasi teks, konteks dan pengarangnya
\end{abstract}

Kata Kunci:

gender; Husein Muhammad; tafsir kontemporer; historisitas teks.

\section{A. PENDAHULUAN}

Husein Muhammad adalah feminis laki-laki yang bertekad membela perempuan dalam aksi dan wacana. Latarbelakang kehidupannya yang dilahirkan dan tumbuh di lingkungan peasantren membuat tokoh ini memliki kemampuan yang baik dalam penguasaan kitab kitab turats. Ia memilih strategi dengan cara membuat penafsiran Alquran terkait relasi gender dengan pendekatan ilmu fikih. Dalam karya-karya dan aksinya, tampak Husein
Muhammad ingin membangun paradigma baru yang lebih segar dalam melihat isu-isu tentang gender.

Tulisan ini bertujuan menjelaskan prinsip penafsiran Husein Muhammad yang telah memadukan analisa gender dan kaidah kaidah penafsiran Alquran dalam karya karyanya.

\section{B. HASIL DAN PEMBAHASAN \\ 1. Biografi Husein Muhammad}

Husein Muhammad dilahirkan di Arjawinangun-Cirebon, 9 Mei 1953. Ibunya 
bernama Ummu Salma Syathori adalah anak dari pendiri pesantren Dār Al-Tauhid Arjawingangun, Bapaknya bernama Muhammad Asyrofuddin dari keluarga biasa yang berpendidikan pesantren.

Husein mengawali pendidikannya dengan belajar membaca Alquran pada Kiayi Mahmud Toha, dan kepada kakeknya(KH. Syathori). Pendidikan formal yang ia tempuh yaitu SD selesai tahun 1966, kemudian melanjutkan ke SMPN 1 Arjawinangun selesai tahun 1969. Husein Muhammad melanjutkan belajar ke Ponpes Lirboyo Kediri setelah lulus SMP selama tiga tahun sampai 1973. Lalu ia melanjutkan pendidikannya ke Perguruan Tinggi Ilmu Alquran (PTIQ) Jakarta dan lulus tahun 1980. Pada tahun ini juga Husein berangkat ke Kairo Mesir untuk melanjutkan kuliah di Universitas Al-Azhar. Setiba di Tanah Air, Husein ditawari untuk mengajar di PTIQ, namun ia lebih memilih pulang kepesantren untuk mengembangkan pesantren kakeknya. Husein kecil yang sudah terbiasa belajar agama dan melihat pembelajaran kitab kuning. Kematangannya untuk persoalan membaca kitab kuning dimulai sejak ia sekolah di pesantren Lirboyo selama tiga tahun. Pengalamannya kuliah di PTIQ seakan melangkapinya untuk dapat tampil sebagai seorang kiyai dimasa datang dengan berbekal beberapa keahlian juga kemampuan menghafal Alquran sebanyak 30 juz secara sempurna.

Adalah Masdar Farid Masudi, ketua dari lembaga P3M (Perhimpunan dan Pengembangan Pesantrendan Masyarakat) untuk mengikuti halaqah dan seminar-seminar yang diadakan oleh P3M. Dari sinilah Husein mulai menerima gagasan-gagasan Islam yang langsung bersentuhan dengan realitas sosial yang selama ini tidak diperoleh Husein di pesantren umumnya. Gagasan-gagasan Husein berubah menjadi lebih progresif dibandingkan sebelum Husein bertemu dengan Masdar. ${ }^{1}$

Husein Muhammad sosok yang unik, karena sosok kiyai yang penghafal Quran dan

${ }^{1}$ M. Nuruzzaman, Kiai Membela Perempuan, Pustaka Pesantren, Yogyakarta 2005, hlm 118 sangat menguasa ilmu-ilmu Islam tradisional. ( ia bukan akademisi) tapi ia adalah dan juga mengenal beberapa pemikiran moderen yang dengan segala upaya dan keterbatasannya tetap menyuarakan pembelaan pada perempuan di even-even nasional maupun internasional. Hal ini dapat dibuktikan dengan prestasinya yang pernah diraihnya di tahun 2006 sebagai "Heroes to End Morn-Day Slavery" dari pemerintah Amerika Serikat, dan tercatat sebagai kiyai pesantren yang paling jujur membela perempuan sehingga namnya tercatat dalam "The 500 Most Influential Muslims (the Royal Islamic Strategeic Studies Center tahun 2010, 20112012) ${ }^{2}$

Sampai tulisan ini dibuat tercata kurang lebih ada 42 karya karya Husein tentang wacana wacana yang sedang ramai diidskusikan, mulai dari HAM-demokrasi, pluralisme, relasi gender, hingga pemikiran tasawuf.

Menurut penulis, Husein Muhammad dapat digolongkan sebagai feminis laki-laki. Karena ia laki-laki yang memeilki kesadaran untuk membela perempuan, ia telah mengusung gagasan feminisme dalam aksi dan wacananya. Dalam aksinya ia telah menulis beberapa karya untuk pembelaan pada perempuan sebagai perjuangannya ditataran wacana. selain itu ia juga berani meng-counter wacana keagamaan yang bias gender dengan basis keilmuan klasik yang biasa digunakan oleh masyarakat umum dan kalangan dalam pesantren

\section{Analisa Gender}

Teori gender bermaksud menstrukturkan dengan benar mana yang kodrati (nature) dan mana yang bentukan atau konstruk budaya dan sosial (nurture) pada kehidupan relasi perempuan dan laki-laki di wilayah domestik

\footnotetext{
${ }^{2}$ Kumpulan tulisan ini kemudian diterbitkan oleh Qalam Nusantara dengan judul buku Perempuan Islam dan Negara Pergukatan Identitas dan Entitas, Cetakan Pertama tahun 2016. lihat kata pengantar di buku ini. Sebenarnya beberapa poin bahsannya sudah ada di beberapa buku lainnya.
} 
maupun di wilayah publik. ${ }^{3}$ Komarudin Hidayat menandaskan, sudah seharusnya dibedakan antara relasi seksual dan relasi gender, relasi seksual itu hubungan antara laki-laki dan perempuan yang didasarkan pada tuntutan dan teori biologis. Sedangkan relasi gender adalah sebuah konsep dan realitas sosial yang merupakan produk dan konvensi sosial yang melibatkan variabel kemampuan dan kualitas individu. Dengan demikian konsep dan manifestasi dari relasi gender lebih dinamis dan memiliki kelenturan dengan mempertimbangkan variabel psikososial yang berkembang. Berdasarkan pemahaman ini, bisa saja seorang yang secara biologis dikategorikan sebagai perempuan, tetapi dari sudut pandang gender berperan sebagai lakilaki ataupun sebaliknya. ${ }^{4}$

Adalah Elaine Showaltaer yang telah mengartikan gender bukan sekedar pembedaan laki laki dan perempuan. Karena menurutnya gender itu sebuah konsep analisis (an analytic concept) yang dapat digunakan untuk menjelaskan sesuatu. ${ }^{5}$ Gender sebagai konsep analisis ${ }^{6}$ melakukan diferensiasi secara tegas antara kodrat sebagai sesuatu yang given from God dan tak dapat dirubah (unchangeable), dengan gender sebagai sebuah konstruk sosial yang bisa dirubah (changeable).Analisa ini dapat diterapkan pada semua lini kehidupa nmanusia.Tidak terkecuali tafsir Alquran.

Menurut Mansour Fakih konsep tentang perbedaan gender (gender differences) dan peran gender (gender role) ${ }^{7}$ adalah konsep

\footnotetext{
${ }^{3}$ Mansour Fakih , Analis Gender dan Transformasi Sosial, (Jogjakarta, Pustaka Pelajar, 2007),hlm. 3-9

4 Komarudin Hidayat dalam "kata pengantar" dalam buku Zaitunah Subhan, tafsir kebencian, hlm xvii-xix

${ }^{5}$ Elaine Showaltaer, (ed) Speaking Gender, (New York \&London : Raoutledge

${ }^{6}$ Disampaikan pada saat pidato pengukuhan guru besar Nina Nurmila, Fiqih Kontemporer Berspektif Keadilan Gender,Pidato Pengukuhan Guru Besar Bidang Fikih pada Fakultas Tarbiyah dan Keguruan UIN Sunan Gunung Djati Bandung. UIN Sunan Gunung djati Bandung, 2018

${ }^{7}$ Pembedaan gender berdasarkan pada sosialisasi gender yang ada dalam sebuah masyarakatLaki-laki dikonsepsikan harus memiliki sikap pemberani,
}

yang paling banyak melahirkan ketidak adailan gender. Indikator ketidak adilan gender itu menurtunya ada dalam lima hal yakni: pertama, marginalisasi yakni bentuk bentuk peminggiran pada jenis kelamin tertentu umumnya perempuan seperti anggapan bahwa perempuan tidak layak jadi pemimpin. Marginalisasi juga sering berujung pada pemiskinan perempuan karena tidak menadapat ruang untuk memperoleh kesempatan kerja. Kedua streotype, yakni pelebelan negatif pada jenis kelamin tertentu umumnya perempuan berakibat pada membatasi, menyulitkan, memiskinkan dan memingirkan perempuan. Ketiga subordinasi yakni merendahkan atau menganggap rendah jenis kelamin tertentu umumnya perempuan misalnya pandangan bahwa perempuan tidak berhak sekolah tinggi. Kempat double/multi burden yakni peran yang harus dimainkan jenis kelamin tertentu umumnya perempuan yang bertumpuk anatara peran publik dan peran domestiknya. Kelima, kekerasan (violence) terhadap jenis kelamin tertentu umumnya perempuan sehingga mereka mengalami pencabulan, pemerkosaan dan juga penganaiyaan fisik, psikis juga ekonomi.

Sedangkan indikator keadilan gender menurutnya ada empat yakni: (1) Akses yakni memiliki kesempatan yang sama untuk memperoleh hak antara laki-laki dan perempuan, misalnya di bidang pekerjaan, perempuan dan laki-laki memiliki kesempatan yang sama secara profesionalitas dan transparan dalam pekerjaan dan perolehan gaji. (2) kontrol, analisa gender untuk mencapai kedailan gender, indikatornya dapat

bertanggung jawab, tegas, dan objektif, sedangkan perempuan cenderung dikonsepsikan harus memiliki sikap lemah lembut, penyayang, berpenampilan menarik, dan rapi. Hal ini memunculkanketidaksejajarangender (gender inequality) dan berpengaruhpadapeletakanposisiperanlaki-laki dan perempuan dalammasyarakatatauyang disebutperan gender (Gender role).Lihat Paul B Horton dan Chester H. Lunt (AlihBahasaAminuddin Ram danTitaSobari), Sosiologi,1999.Hlm. 161. 
dilihat melalui daya kontrol pemahaman atau pembangunan yang menguntungkan untuk perempuan dan laki-laki yang memilki kebutuhan dasar yang sama. (3) partisipasi, meningkatnya peran serta perempuan dan lakilaki dalam beberapa bidang kehidupan baik wilayah domestik atau publik sehingga aspirasi mereka dapat diwadahi dan tersalurkan juga merupakan indikator terciptanya keadilan gender .(4) perempuan dan laki laki yang dapat merasakan manfaat dari pembangunan. Contohnya tersedianya pojok Asi di area publik. ${ }^{8}$

Seperti pada analisa masalah perempuan, target analisa gender yang diterapkan dalam penafsiran Alquran semata menjaga agar hasil tafsir Alquran terhindar dari bias gender (ketidakadailan gender), sehingga sebuah tafsir menjadi adil gender. Tafsir semacam ini lebih dikenal dengan sebutan tafsir feminis. Tafsir dengan pendekatan feminisme ini umumnya diciptakan oleh kaum feminis. ${ }^{9}$

Tafsir feminis lahir sebagai keniscayaan dari sebuah kerja akademik. Tafsir feminis merupakan konsep yang kaitannya merujuk kepada perubahan sosial (social change), teori-teori pembangunan, kesadaran politik perempuan dan gerakan pembebasan kaum perempuan, termasuk memikirkan kembali institusi keluarga dalam konteks masyarakat hari ini.

Jika dibandingkan antara tafsir feminis dan tafsir patriarkal, akan ditemukan beberapa hal yang berbeda secara diametral antara keduanya yakni; Pertama : Penafsiran secara literalistik-skripturalistik atas ayat-ayat Alquran memang sangat dominan dalam kitabkitab tafsir patriarkal. Yakni sebuah upaya mencari kejelasan makna yang dilakukan secara harfiah oleh para mufassir klasik, dan mengesampingkan sama sekali pendekatan historis-kontekstual terhadap teks-teks

\footnotetext{
${ }^{8}$ Fakih, Analisa Gender... .Hlm. 73-76

${ }^{9}$ Feminis adalah leki laki atau prempuan yang memilki kesadaran akan adanya persoalan kehidupan yang ditimbulkan dari relasi gender yang tidak seimbang ia lalu melakukan perubahan melalui aksi dan wacana.
}

Alquran tersebut. Hal ini bukan berarti tafsir klasik mengabaikan aspek asbāb al-Nuzūl sebagai pemberi arah penafsiran mereka, namun kadangkala keberadaan asbāb al-Nuzūl di tangan mereka lagi- lagi dipahami secara litralistik-skriptualis.

Kedua, dari sisi pengambilan sumber tafsir antara tafsir feminis dengan tafsir patriarkal misalnya, jika tafsir patriarkal seringkali mengambil sumber yang berasal dari israiliyat seperti sejarah dan mitologi kejatuhan Adam dan Hawa dari surga, maka mufasir feminis memandang hal lain yang tidak kalah pentingnya dengan memperhatikan ayat ini dari sisi lain, misalnya dari sisi ke universal ayat ('am) atau ke-partikularannya (khas).

Ketiga, Paradigma tafsir feminis ini memang akan 'bertabrakan' dengan paradigma lama dalam penafsiran patriarkhi yang selama ini menganggap ayat-ayat yang berkaitan dengan relasi gender sebagai ayat-ayat qath'iyyu al-dalalah (ayat yang sudah mapan dan pasti penafsirannya). Sedangkan, par amufassir feminis beranggapan bahwa ayatayat relasi gender lebih merupakan ayat-ayat yang bersifat sosiologis yang penafsirannya bersifat kontekstual sesuai dengan perubahan sosial masyarakat.

Keempat, kegelisahan para mufassir feminis antara lain disebabkan ketika mereka membaca produk tafsir patriarkhal, ternyata kurang mencerminkan keadilan gender. Padahal pandangan dunia (world view) Alquran jelas-jelas ingin mendudukkan lakilaki dan perempuan secara setara (equal). Banyak isyarat ayat yang menyatakan bahwa laki-laki dan perempuan adalah sama di hadapan Allah, yang membedakan hanyalah tingkat ketakwaannya kepada Allah. Kondisi atau konteks yang berubah inilah yang hendak disikapi oleh para mufassir feminis untuk mencoba merespon ayat-ayat yang secara tekstual-literal mengandung bias-bias patriarkhi. Jadi, sama sekali tidak bermaksud merubah Alquran, tetapi memberi alternasi baru dalam memahami Alquran, yakni dengan menangkap gagasan utamanya (maghza) di balik makna literal. 
Kelima, mufassir feminis menggunakan model pendekatan Hermeneutik ${ }^{10}$ dalam menafsir Alquran, metode itu mempunyai pandangan yang kritis dalam tiga aspek, yaitu: 1) konteks apa teks itu ditulis. Jika kaitannya dengan Alquran, maka dalam konteks apakah ayat itu diturunkan (baca: asbāb al-nuzūi), 2) Bagaimana komposisi tata bahasa teks (ayat) tersebut, bagaimana pengungkapannya, apa yang dikatakannya, 3) Bagaimana keseluruhan teks (ayat) berbicara terhadap tema tertentu, lalu bagaimana pula Weltanchauung-nya. Atau pandangan hidup. Oleh sebab itu, model pendekatan ini, melihat bahwa ayat-ayat yang secara tekstual bias gender, seperti ayat pembagian hukum waris, persaksian, poligami dan sebagainya, yang sebenarnya dapat dijelaskan secara lebih kontekstual.

Keenam Konsekuensi dari pendekatan Hermeneutika, dalam menafsirkan Alquran tidak terbatas pada pendekatan keilmuan yang digunakan para penafsir dulu, seperti ilmu nahwu sharaf, ushul fikih dan balaghah, tetapi diperlukan ilmu-ilmu lain seperti teori sosiologi, antropologi, filsafat ilmu, sejarah, gender dan sebagainya.

\section{Prinsip-prinsip Penafsiran digunakan Husein Muhammad}

Husein Muhammad membedakan secara tegas istilah tafsir dan ta'wïl. Menurutnya meskipun tafsir dan $t a$ 'wil seringkali dimaknai sama, namun sebenarnya dua istilah ini berbeda. ${ }^{11}$ Husein Muhammad lebih memilih

\footnotetext{
${ }^{10}$ Sebagaimanadinyatakan Roger Triggbahwaparadigmahermeneutikadalah:"The paradigm for hermeneutics is interpretation of the traditional text, where the problem must always be how we can come to understand in our own context something which was written in radically different situation". ${ }^{10}$ Arkoun, Rethingking Islam, Terj. Yudian Wasmin.hlm. 65.

${ }^{11}$ Tafsir dimatanya lebih berkaitan dengan riwayah (informasi, nukilan atau berita) dalam memahami teks Alquran, Tafsir lebih memperhatikan makna tekstual atau literal dan kurang memperhatikan makna alegoris atau metaforis. Karena dalam teori tafsir jika makna kata itu memiliki makna literal dan metafor maka yang diutamakan untuk dipilih adalah makna literal. Karena tafsir identik dengan pendekatan tekstual dalam memahami mkan kata, maka tafsir seingkali mengabaikan psikososial yang melingkupi. Ia Setuju
}

ta'wìl dari pada tafsir dalam memahami makna dari teks-teks Alquran. Menurutnya ta'wil memiliki tata kerja yang memungkinkan sesorang memahami makna universal dan partikular dari lafadz itu, memiliki tata kerja berkaitan dengan dirayah (pemahaman)pada isi-dan subtsansi teks, jika satu kata memliki dua makna (literal dan metafor) maka ta'will lebih menekankan pada analisa makna substantif, pada maksud dan tujuannya. Selain itu kehendak ta'wïl bukan sekedar memahami teks dari makna tekstualnya, melainkan pada logika dan filosofi maknanya. Oleh karena itu taw'il meniscayakan pengetahuan tentang konteks yang menyertai isu itu sendiri, konteks sosial dan budaya politik yang melingkupinya ${ }^{12}$ Nampaknya dimatanya ta'will identik dengan Hermeneutika.

Untuk mempertegas penggunaan ta'wil (yang sebenarnya Hermeneutika) Husein Muhammad, merujuk pada pendapat alShatibi dan al-Ghazali, bahwa untuk memahami teks bahasa Arab dimana Alquran diturunkan diperlukan pengetahuan tentang sejumlah kondisi dan konteks (muqtdhayat alahwal), kondisi bahasa (nafs al-lughah), konteks mukhathab (audiens), konteks mukhathib (pembicara), dan yang tidak kalah pentingnya adalah pemahaman dan pengetahuan pada kontek konteks yang lebih luar (al-umur al-kharijiyyah) yakni pemahan terhadap adat istiadat masyarakat Arab dalam berbahasa, bertingkal laku dan berinteraksi ketika Alquran diturunkan. ${ }^{13}$ Pemahaman terhdap teks dapat juga dilakukan dengan menggunakan nalar rasional (ihalah 'alä dalil al-Naql), melalui indilkasi-indikasi sejumlah

dengan pendapat Abu Nasr al-Qusyairi bahwa dalam tafsir itu yang diutamakan mendengarkan dan mengutip

${ }^{12}$ Muhammad, Perempuan Islam Dan Negara Pergulatan Identitas Dan Entitas., hlm 122 dan Muhammad, Ijtihad Kiyai Husein Upaya Membangun Keadilan Gender., hlm. Xv.

${ }^{13}$ Husein Muhammad tafsir alquran dalam persepektif perempuan dalam Modul kursus Islam dan Gender hal 81. Bandingkan dengan abu Ishaq alSyathibi al-Muwafaqot fiushul al-Syari'ah, al Maktabah al- Tijariyah, Mesir, tt, jilid III hlm 347-351 
konteks, isyarat-isyarat, simbol simbol (rumuz). perubahan-perubahan (harakat), konteks yang mendahuluinya (al-sawabiq) dan lawahiq (konteks yang menyertainya) serta hal-hal yang tidak terbatas. ${ }^{14}$

Pola pemaham teks diatas jika dicermati sebenarnya adalah pola-pola yang biasa digunakan dalam hermeneutika. Hermeneutika merupakan sebuah metode yang tidak tidak hanya memandang teks dan menyelami kandungan makna literalnya, tetapi berusaha menggali makna dan mempertimbangkan horison-horison yang melingkupi teks tersebut. Horison yang dimaksud adalah horison teks, horison pengarang dan horison pembaca. $^{15}$

Untuk memperjelas uraian diatas, penulis akan mengelaborasikannya pada beberapa prinsip-prinsip pemahaman teks yang dipegang teguh oleh Husein dalam memahami ayat-ayat relasi gender dalam karya karyanya.

Pertama, Prinsip Alquran sebagai kitab Hidayah, berdasarkan pada beberapa ayat Alquran, ia mengasumsikan bahwa Alquran adalah kitab petunujuk (hidāyah) dan rahmat. Baginya, Alquran sudah menjelaskan dengan terang bahwa ia adalah buku hidayah (hudan li al-nas) dan untuk menebar kerahmatan semesta (rahmatan lil 'alamin). Kedua pernyataan ini menurutnya memberikan penjelasan bahwa Alquran merupakan kitab (bacaan) yang terbuka (inklusif) bagi setiap manusia dimanapun dan kapanpun terhadap orang-orang yang menginginkan terwujudnya sistem kehidupan yang berkeadilan, merahmati, dan yang mensejahterakan seluruh umat manusia. Terma kerahmatan ini mengandung makna kebaikan, kasih sayang, cinta kebebasana, kesetaraan, keadailan, dan norma norma kemanusian lainnya. Menurutnya hakikat dari nilai-nilai itu adalah

14 Husein Muhammad tafsir alquran dalam persepektif perempuan dalam Modul kursus Islam dan Gender hal 82. Bandingkan dengan Abu Hamid alGhazali, al-Musthafa min ilm al-Ushul, Maktabah alJundi, Mesir, tt, hlm 268 hal

${ }^{15}$ Komarudin Hidayat, Memahami Bahasa Langit, tujuan moral yang ingin diwujudkan dalam tata kehidupan manusia, nilai-nilai tersebut menurutnya diturunkan dan dikembangkan dari prinsip utama Islam yakni tauhid. ${ }^{16}$ Artinya, Husein Muhammad menekankan bahwa Alquran adalah korpus terbuka untuk diakses oleh manusia dalam mewujudkan universalime Islam.

Kedua, memahami Alquran berarti Mengetahui dengan jelas kondisi dan konteks (muqtdhayat al-Ahwal) dari ayat yang akan dibahas. Prinsip ini kemudian dielaborasaikan pada pentingnya bagi seseorang yang akan memahami Alquran mengetahui asbāa alNuzūl, makiyyah-madaniyyah dan muhkammutashabbih. Tentunya pemaparan dan batasan-batasanya pada tiga asepek tersebut sesuai dengan apa yang sudah dijelaskan pada bahasan sebelumnya.

Ada yang menarik dari pandangan Husein tentang tiga hal di atas. Bagi Husein $a s b \bar{a} b$ alNuzūl merupakan kajian sejarah tradisi manusia secara makro (bukan mikro) pada saat turunnya Alquran. Artinya mengetahui asbāb al-Nuzūl berarti memahami nila-nilai universal dari respon Allah pada manusia secara keseluruhan, bukan hanya pada masyarakat Arab saat itu saja.

Dengan tegas Husein menuliskan bahwa :"Pada akhirnya, keputusan apapun yang didasarkan atas teks teks Islam harus merefleksikan tujuan-tujuan moral, makna dan konotasi dari nilai-nilai moral ini harus dieksplorasi dengan nalar, intuisi dan observasi-observasi atas hukum alam yang bersifat sosial"17

Di mata Husein ayat makiyyah menekankan pada ketauhidan, nilai-nilai kemanusiaan universal (kesetaraan manusia, keadilan, keesaan, pluralitas, dan penghargaan pada manusia) sebagai tujuan utama agama ${ }^{18}$ teksteks Alquran pada periode itu mengandung

\footnotetext{
${ }^{16}$ Husein Muhammad, Mengaji Pluralisme Kepada Mahaguru Pencerahan (Bandung: Mizan, 2011)., hlm. 54 .

${ }^{17}$ Husein Muhammad, 'pengantar penulis , dalam buku Ijtigah kyai Husein... hlm xlix

${ }^{18}$ Husein Muhammad ijtihad Kyai .. hlm xxvi
} 
gagasan yang progresif dan revolusioner. ${ }^{19}$ sementara ayat-ayat madaniyah umumnya berisi penetapkan aturan-aturan yang lebih rinci, lebih spesifik dan partikular yang menyangkut problem-problem aktual yang diahadapi masyarakat Madinah. Beberapa diantaranya berkaitan dengan hukum-hukum personal, hukum keluarga, dan aturan aturan tentang kehidupan bersama dalam masyarakat plural yang telah terbentuk disana ${ }^{20}$

Penting dijelaskan lagi disini, keberadaan makiyyah dan madaniyyah di mata Husein adalah kenyataan sejarah Alquran penting dikemukakan agar dapat dipahami bahwa kitab suci ini senantiasa melakukan dialog secara dinamis dan akomodatif, bernegosiasi dan melakukan interaksi dengan akal dan psikososial masyarakat Arab abad ke 7M dan dengan subyek audien yang tidak tunggal. ${ }^{21}$

Sedangkan ayat-ayat muhkam menurutnya lebih merujuk pada prinsip-prinsp dasar kebenaran bersifat universal, seperti tauhid, keadadilan, persamaan hak, dan kesetaraan manusia di muka hukum. Sedangkan ayat-ayat mutashabihat adalah ayat-ayat yang berkaitan dengan aspek aksiologis tentang bagaimana menetapkan ayat-ayat termasuk dalam kategori muhkam ini. Dengan kata lain, ayatayat mutashabihat cenderung bersifat teknis partikular, sedangkan ayat-ayat muhkamat bersifat normatif - universal. $^{22}$

Menurut analisa penulis, pandapat Husein ini seolah menunujukan bahwa ayat-ayat makiyyah umumnya ayat muhkam karena ayat makiyyah menenkan ketauhidan dan nilai-nilai kemanusiaan universal sebagai tujuan agama. Sedangkan ayat-ayat madaniyyah adalah ayatayat mutashabihat karena umumnya berisi penetapkan aturan-aturan yang lebih rinci, lebih spesifik dan partikular yang menyangkut problem-problem aktual pada saat itu.

\footnotetext{
${ }^{19}$ Husein Muhammad, Modul Kursus..., hlm. 95

${ }^{20}$ Dalam hal ini ia sependapat dengan al-Suyuthi dan al-ZarkasyiPendapat ini

${ }^{21}$ Husein Muhammad, pengantar dalam buku ijtihad kiya, hlm xxii

${ }^{22}$ Husein Muhammad, Perempuan, Islam dan Negara, pergulatan Identitas dan entitasQalam Nusantara, yogyakarta, cet i , 2016hlm 124
}

Ketiga memahami kondisi bahasa (nafs alLughah) misalnya melakukan diferensiasi antara narasi berita dan narasi perintah atau larangan dalam memahami aspek cara mengungkap sisi petunjuk dalam Alquran . Menurutnya petunjuk itu dinarasikan pada dua bentuk, yakni narasi berita (khabari, deskriptif) kedua narasi perintah atau larangan (thalabi, preskreptif). Yang harus selalu diperhatikan menurutnya bahwa melakukan pemahaman narasi perintah atau larangan itu tidaklah mudah. Preksriptif tidak selalu bermakna kewajiban (li al-Qujub) dan keharaman (li al-Tahrim). Perintah dapat diartikan anjuran, saran atau himbauan, bahkan ancaman. Larangan dapat diartikan peringatan, tidak dianjurkan dan sebagainya. Pemahaman terhadap hal- hal tersebut memerlukan referensi-refensi (dilalah) lain yang mendukungnya. Narasi pereksriptif inilah yang kemudian banyak menjadi perhatian bagi ahli hukum (fuqahā). ${ }^{23}$

Keempat, prinisp berikutnya dalam memahami teks Alquran, sesorang harus dengan jelas mengetahui konteks mukhatab (audiens), konteks mukhatib (pembicara), sesorang harus lebih dulu mengetahui apakah ayat ini berkaitan dengan pembahasan akidah, ibadah, atau muamalah, karena dengan mengetahui hal tersebut seorang pembaca Alquran dapat memhami posisi mukhatib berbicara sebagai naqid, mukhbir atau mubtakir. Sedangkan menyertakan pengetahuan tentang audien (mukhatab) ketika memahami Alquran dapat menjaga dari kesalahan pemahaman tentang maksud ayat. Posisi mukhatab yang dimaksud dalam ayat yang sedang dikaji dapat diketahui dengan melihat pada asbāb al-Nuzūl atau kajian pada apakah ayat ini makiyyah atau madaniyah. Kedua kajian itu hakekatnya dapat membantu seorang pengkaji Alquran mengetahui tradisi, adat istiadat masyarakat Arab dalam berbahasa, bertingkah laku dan berinteraksi ketika teks-teks Alquran

\footnotetext{
23 Husein Muhammad, Pengantar penulis dalam Ijtihad Kiyai Husein hlm. xvii
} 
diturunkan (al-umur al-kharijiyyah) dari ayat itu sekaligus juga memperkaya pengetahuannya tentang horison teks baik tentang al-sawabiq (konteks yang telah lalu) dan lawahiq (konteks yang menyertainya) serta hal-hal yang tidak terbatas lainnya.

Kelima, menurutnya teks Alquran yang bersifat partikular tidak dapat membatasi teks universal. ia melakuakan prinsip melakukan diferensiasi antara ayat ayat partikular dan ayat ayat universal. Menurut Husein ada dua kategori teks, yakni teks-teks universal dan teks-teks partikular. Teks universal adalah teks yang mengandung prinsip-prinsip kemanusian untuk semua orang disegala ruang dan waktu (kemanusian universal) dinataranya yang tertuang dalam DUHAM dan juga kulliyat alKhams-nya al-Ghazali. Teks universal ini menurut Husein adalah apa yang dikategorikan muhkamat oleh pada ulama. ${ }^{24}$

Sedangakan teks partikular adalah teks teks yang menunjukan pada kasus tertentu. Teks partikular muncul sebagai respon atas suatu kasus atau peristiwa, oleh karena itu teks ini bersifat selalu terkait dengan kasus tertentu, karenanya teks partikular harus dimaknai secara kontekstual. Isu-isu kepemimpinan laki-laki atas perempuan, perwaliyan perempuan, poligami, kewarisan dan lain lain adalah contoh teks-teks partikular. Ia juga termasuk pada kategori Mutashabihat, interpretable, dan dapat dinterpretasikan karena dapat menghasilkan pemahaman yang berbeda-beda.

Mayoritas ulama ahli hukum biasanya berpendapat bahwa jika terjadi pertentangan anatara teks universal dan teks- tesk partikular, maka teks partukular membatasi teks universal. Husein Muhammad mengikuti pendapat al-Shatibi yang menolak pandangan di atas ${ }^{25}$. Artinya baginya teks partikular tidak dapat membatasi teks universal. Alasan yang dipegangnya bahwa ia percaya pesan pesan agama yang ditulis dalam teks Alquran itu selalu mengandung tujuan dan ruh

\footnotetext{
${ }^{24}$ Muhammad, Perempuan Islam Dan Negara Pergulatan Identitas Dan Entitas., hlm.124.

${ }^{25}$ Muhammad., hlm.124.
}

kemanusian. Tujuan ini dapat dipelajari dan diwujudkan karena ia bersifat rasional, dan bukan hal yang harus terkait dengan kebenaran scriptural. Prinsip inilah yang kemudian melahirkan prinsip berikutnya, yakni prinsip hasil penafsiran sebagai bentuk pemahaman dari teks Alquran tidak boleh bertentangan maqāid al-Shari'ah atau kulliat al-Khams.

Dari paparan di atas, kiranya dapat dipahami Husein Muhammad telah melakukan pergesaran paradigma (paradigm shift) dalam memahami konep muhkam-mutsasyabih, dan nasikh- mansukh. Berawal dari pernyataannya bahwa makiyyah adalah adalah ayat ketauhi dan kemanusiaan universal sebagai tujuan agama, ayat ini olehnya digolongkan pada ayat ayat universal. Sedangkan madaniyyah merupakan ayat-ayat yang mengandung ajaran dan aturan kehidupan persoanal, keluarga dan hal hal yang lain yang bersifat partikular (alAhwal al-Shakhsiyah), olehnya ayat madaniyyah digolongkan pada ayat-ayat partikular atau ayat mutashabihat. Maka jika terjadi pertentangan antara ayat universal dan ayat partikular, yang diutamakan adalah ayat universal bukan ayat partikular (padahal umunya ulama fikih berpendapat sebaliknya). Solusi yang ia tawarkan berarti ayat universal yang isinya ayat makiyyah dan ayat muhkamat versinya itu dapat menjadi nasik (penunda) atas ayat-ayat madaniyyah yang partikular dan mutashabihat. Sampai batas ini ia nampak mengikuti apa yang sudah dipolakan oleh Mahmud Muhammad Toha bawa ayat-ayat makiyyah dapat menaskh ayat-ayat madaniyyah.

Meskipun demikian, menurut hemat penulis, konsep-konsep Husein tetap besifat "subjektif", sebab dalam Alquran sendiri tidak ada penjelasan secara tegas yang menyatakan bahwa muhkamat adalah ayat-ayat hukum dan mutsayabihat itu ayat non hukum, mana kelompok ayat makiyyah dan mana kelompok ayat madaniyyah, mana kelompok ayat yang menjadi nasikh dan mana yang menjadi mansukh demikian setrusnya. Efek langsung dari prinsip diatas adalah prinsip 
Keenam, bahwa hasil penafsiran sebagai bentuk pemahaman dari teks Alquran tidak boleh bertentangan maqasidal-syariah atau kulliat al-Khams. Sebenarnya prinsip ini berjalin kelindan dengan basis teologi pemikirannya tentang konsep tauhidullah dan asumsi dasar bahwa Alquran itu petunjuk dan rahmat lil 'alamin.

Prinisp di atas mencerminin premis mayor dari pemikiran Husein adalah menganggap bahwa Alquran itu hudān Iì al-Nās (petunjuk bagi manusia) dan rahmatan $\overline{l i}$ al-'Alamin (kesejahteraan bagi manusia), oleh sebab itu maka pemahaman pada teks Alquran harus sejalan dengan prinsip maqasid al-Shari'ah.

Pada tataran operasional dari premis di atas, Husein Muhammad melakukan penafsiran dengan menggunakan analisa gender. Tafsir bagi Husein Muhammad harus terhindar dari lima indikator ketidakadilan gender dan mengarah pada keadailan gender

Ketujuh, menurut Husein Muhammad, Pemahaman atas teks juga bisa dilakukan dengan menggunakan nalar rasional (ihalah 'ala dalil al-Naql), melalui indilkasi-indikasi sejumlah konteks, isyarat-isyarat, simbolsimbol (rumuz). perubahan-perubahan (harakat), konteks yang mendahuluinya (alsawabiq) dan lawahiq (konteks yang menyertainya) serta hal-hal yang tidak terbatas.

Premis diatas dioperasionalkan dalam penafsirannya dengan menggunakan pendekatan kontekstual dalam penafsiran. Seperti umumnya ulama kontemporer, Husein Muhammad juga meyakini bahwa penafsiran Alquran harus kontekstual dan mampu memberikan solusi bagi problem yang dihadapi masyarakat muslim. Prinsip ini didasarkan pada keyakinan bahwa Alquran itu rahmatan Ii al-'Alamīn. Rahmat menurtnya adalah riqqah al-Qalb (kepekaan hati), alTa'afuf (kelembutan jiwa), dan al-Magfirah (pemaafan). Maka kerahmatan Alquran ini adalah prinsip yang dapat menimbulkan keindahan, kedamaian dan penuh kebaikan bagi yang dirahmati. Sehingga meniscayakan berlakunya nilai- nilai dan norma- norma kemanusian universal, karena norma-norma itu wujud dan ekspresi dari keimanan pada kemahaesaan Allah ${ }^{26}$

Kedelapan, Prinsip Sunnah Nabi Sebagai Metode Ijtihad. Sunnah nabi disini tentu saja bukan hadis-hadis literal yang sudah dibukukan dalam kitab kitab hadis populer dan ternama. Jika selama ini sunnah nabi dijadilkan sumber hukum dalam ijtihad, maka tidak demikian halnya dengan Husein. Ia menganggap sunah nabi sebagai produk ijtihad nabi yang dinamis. Menurutnya agak sulit jika memahami Alquran hanya dilakukan sendiri tanpa mmeperhatikan sejarah kehidupan nabi, karena ayat-ayat itu bersifat situasional, dan juga tidak mungkin ayat-ayat iti diajarkan tanpa menyinggung aktifitas nabi yang meliputi politik, ekonomi dan pengambilan keputusan. Oleh sebab itu, hanya dengan mengetahui kehidupan nabi dan zamanya, ajaran Alquran akan memiliki pertalian yang logis. Sebab itu sunnah nabi memiliki posisi yang penting. Dan sunnah nabi itu harusnya diinterpretasikan pada nilainilai yang dapat diadaptasikan dengan konteks kekinian. Konsep sunnah menurut Husein Muhammad adalah konsep pengayoman daripada sebuah kandungan khusus yang mutlak. ${ }^{27}$

Kesembilan, Husein mendasarkan penafsirannya pada prinsip-prinsip agama Islam, yaitu keadilan ('adalah), musyawarah (shura), persamaan (musawah), menghargai kemajemukan (ta'addudiyah), bertoleransi terhadap perbedaan (tasamuh), dan perdamaian (ishlah). Premis ini kemudian dioperasionalkan dengan cara memfokuskan pada bahasan HAM sebagai basis pemikiran feminisnya.

Sebagai implementasi dari prinsip prinsip diatas dapat dilihat penafsirannya dalam buku Modul Daurah Fiqh Perempuan, Husein menjelaskan secara gamblang tentang bagaimana seharusnya seorang mufasir mengkaji kausalitas dan maksud teks, dalam

\footnotetext{
${ }^{26}$ Husein Muhammad, Dauroh Fikih Perempuan,hlm. 78, bandingkan dengan pengantar husein Muhammad untuk buku Ijtihad Kiyai Husein .

${ }^{27}$ Husein Muhammad, "Tafsir al-Qur'an... hlm 235
} 
menjaga dan menjalankan prinsip ini Husein Muhammad menggunakan prinsip tentang kausalitas, seperti ketika membahas tema $D i$ Balik Batas Aurat Perempuan. Langkah pertama yang dilakukan Husen adalah mendefinisikan definis aurat berdasarkan pada kata-kata aurat dalam Alquran, ia kemudian menjelaskan perbedaan pendapat yang ada di kalangan ulama tentang batas batas aurat bagi perempuan. Lalu menarik kesimpulan awal bahwa perbedaan pendapat di kalangan ulama madzhab tentang batas aurat perempuan itu semata karena pemahamn mereka yang beragam tentang hadith Rasul yang berkaitan dengan hal ini. Mereka kemudian membagi batas aurat perempuan itu berdasarkan pada apakah perempuan itu seorang hamba yang harus bekerja di ruang publik, ataukah perempuan itu seorang yang merdeka yang hanya bekerja di ruang domestik. Husein kemudian menjelaskan beberapa thariqah Istimbath yang dilakuakan ulama madzhab dan kemudian ia mengungkapkan bahwa beragamnya pendapat ulama tentang batas aurat perempuan itu bermuara pada dua alasan yang pertama boleh membuka aurat jika demi keperluan ( talbiyat li al-Hajah), atau demi menghindarti kesulitan (daf'an li al-Kharaj), setelah itu kemudian menggais bawahi bahwa jika disetujui " kesulitan " dan "keperluan" itu faktor penentu dalam menginterpretasikan batas aurat perempuan, maka batas aurat itu bukan terminologi agama, artinya batasnya tidak ditentukan oleh teks teks agama. Kalau aurat dalam hal ini sama halnya dengan kata kata lain, seperti aib, dan memalukan, atau sebaliknya wajar dan sopan. Aurat menjadi termonologi sosial budaya yang sangat relatif, berbeda dari satu tempat ke tempat yang lain. ${ }^{28}$

Husein kemudian mengambil kesimpulan bahwa, menutup aurat merupakan perintah dari agama, namun mengenai batas aurat ditentukan oleh pertimbangan-pertimbangan kemanusiaan dari segala aspek. Diperlukan

\footnotetext{
${ }^{28}$ Husein Muhammad, Tafsir al-Qur'an dalam perspektif perempuan" dalam modul kursis Islam dan Gender: Dauwroh Fiqih Perempuan, Cirebon: Fahmina Institut, 2007 hlm 342
}

makanisme tertentu yang akomodatif dan responsif terhadap berbagai nilai yang yang berkembang di masyarakat, sehingga dalam tingkatan tertentu batasan itu dapat diterima sebagian besar komponen masyarakat. perlu dipertimbangkan adalah khauf al-Fitnah (takut akan terjadi fitnah) yang sudah dikembangkan oleh ulama fikih agar tidak terjadi eksploitasi pada tubuh manusia, yang hanya sebatas kepentingan murahan atau menimbulkan gejolak fitnah yang dapat merusak tatanan kehidupan bermasyarakat. ${ }^{29}$

Menurut Husein, memahami Alquran sebagai kitab suci yang tengah berdialog secara dinamis dan interaktif dengan akal dan budaya Arabi abad dimana Alquran itu diturunkan, yakni dalam konteks sosial yang berbeda. Itu artinya ada hal menarik dari Alquran bahwa ia hadir tidak dalam kerangka meruntuhkan seluruh dan total atas bangunann tradisi, adat istiadat dan budaya masyarakat waktu itu. Alquran memberika respon positif bahkan pandangan pandangan yang appersiatif terdahap tradisi dan budaya lokal, tetapi dalam waktu yang bersamaan ia juga mengemukakan pandangan-pandangan baru yang didasari oleh cita cita besar kemanusiaan. Oleh karena itu, baginya teksteks Alquran itu hadir untuk melakukan proses-proses transformasi terhadap kebudayaan masyarakat Arab tanpa merusaknya secara total dan revolusienar menuju terwujudnya konstruksi sosial baru yang lebih baik. ${ }^{30}$ Berdasarkan hal inilah melakukan kontekstualisasi dalam penafsiran artinya dapat memenuhi nilai-nilai kerahmatan dan juga hudān (petunjuk) yang ada pada Alquran itu sendiri

\section{SIMPULAN}

Sebagai feminis muslim, Husein Muhammad telah mencoba merespon persoalan kehidupan kontemporer dengan paradigma metodologis tafsir feminis. Prinsip-prinsip pernafsirannya sebenarnya

\footnotetext{
${ }^{29}$ Muhammad, Fiqh Perempuan Refleksi Kiyai Atas Wacana Agama Dan Gender., hlm 67-86.

${ }^{30}$ Husein Muhammad, Modul kursus Islam dan Gender, Dawrah Fiqih Perempuan, hlm. 79.
} 
bernuansa Hermneutis. Hanya saja ia tidak melandaskan pikirannya pada para filosof barat. Dengan jeli ia telah melandaskan pemikirannya pada dua pemikir ternama di dunia Islam yakni al-Ghazali dan al-Shathibi. Prinsip penafsiran yang berkaiatan dengan teks yang diambil dari al-Shathibi prinsip tentang pengetahuan sejumlah kondisi dan konteks (muqtdhayat al-ahwal), kondisi bahasa (nafs al-Lughah), konteks mukhatab (audiens), konteks mukhatib (pembicara), Sedangkan prinsip pemahamn dari sisi horison konteks teks dengan mengetahui konteks yang lebih luar (al-Umur al-Kharijiyyah) yakni pemahaman tentang tradisi, adat istiadat masyarakat Arab dalam berbahasa, bertingkal laku dan berinteraksi ketika teks-teks Alquran diturunkan. Pemahaan atas teks juga bisa dilakukan dengan menggunakan nalar rasional (ihalah 'ala dalil al-Naql), melalui indilkasiindikasi sejumlah konteks, isyarat-isyarat, simbol simbol (rumuz). perubahan-perubahan (harakat), konteks yang mendahuluinya (alsawabiq) dan lawahiq (konteks yang menyertainya) serta hal-hal yang tidak terbatas

\section{DAFTAR PUSTAKA}

Fakih, Mansour. Analisis Gender Dan Transformasi Sosial. Yogyakarta: Pustaka Pelajar, 1996.

Muhammad, Husein. Fiqh Perempuan Refleksi Kiyai Atas Wacana Agama Dan Gender. Yogyakarta: LKIS, n.d.

$\begin{array}{lll}\text { Menurut Islam," } 1995 . & \text { Peproduksi }\end{array}$
Membangun Keadilan Gender. Jakarta: Rahima, 2001.

- Mengaji Pluralisme Kepada Mahaguru Pencerahan. Bandung: Mizan, 2011.

- Perempuan Islam Dan Negara Pergulatan Identitas Dan Entitas. Yogyakarta: Qalam Nusantara, 2016.

- Modul Kursis Islam Dan Gender: Dauwroh Fiqih Perempuan. Cirebon: Fahmina Institut, 2007.

Al-Suyuti. Al-Itqan. Kairo: Dar al-Turats alTa'lim wa al-Tarbiyah fi al-Islam, n.d.

Mas'udi, Masdar F. Perempuan Di Antara Lembaran Kitab Kuning Dalam Lies Marcoes Natsir Dan Jhon Hendrik Meuleman (Ed.), Perempuan Islam Indonesia Dalam Kajian Tekstual Dan Kontekstual. Jakarta: INIS, 1993.

Nurmila, Nina Fiqih Kontemporer Berspektif Keadilan Gender,Pidato Pengukuhan Guru Besar Bidang Fikih pada Fakultas Tarbiyah dan Keguruan UIN Sunan Gunung Djati Bandung. UIN Sunan Gunung djati Bandung, 2018

M. Nuruzzaman, Kiai Membela Perempuan, Pustaka Pesantren, Yogyakarta 2005

- Hidayat, Komaruddin. Memahami Bahasa Agama. Jakarta: Paramadina, 1996. 